\title{
Disrupting the habit of interviewing
}

\author{
Eileen Honan e.honan@uq.edu.au
}

\section{Abstract}

This paper contributes to the growing domain of 'post-qualitative' research and experiments with a new (re)presentational form to move away from traditional and clichéd descriptions of research methods. In this paper, I want to interrogate the category of interview, and the habit of interviewing, to disrupt the clichés, so as to allow thinking of different ways of writing/speaking/representing the interactions between researcher and researched that will breathe new life into qualitative inquiries. I will attempt to flatten and shred, destabilise and disrupt our common-sense ideas about interview, including those held most sacred to the qualitative community, that of anonymity and confidentiality, as well as the privilege of the 'transcript' in re-presenting interview data.

Key words: post-qualitative research; Deleuze; reconceptualizing interviews

\section{A beginning}

This paper contributes to a growing field of work within the 'post-qualitative' domain (St Pierre, 2012), where researchers attempt to "imagine and accomplish an inquiry that might produce different knowledge and produce knowledge differently" (Lather, 2013, p. 635). Within the field of 'post-qualitative' research, attention is being paid to all aspects of the research inquiry, from interrogating the nature of 'data' itself, through to the methods of conducting research (Lather \& St. Pierre, 2013). In this paper, I respond to Lather and St Pierre's questions about rethinking research problems and deconstructing the "privileged face-to-face methods" $(2013$, p. 630) of interviewing and observations. In particular, I want to interrogate the nature of the interview, and the common taken-for-granted assumptions made, especially by early career researchers, about the habitual practices associated with this particular data collection method.

There is a habit of interviewing that has seeped through the fabric of educational research, so the act, the process, appears invisible, as a dark stain on a complicatedly patterned shirt, (it's alright you can hardly see it, don't worry about it). Early career researchers and doctoral students undertaking research writing for the first time glibly and unreflexively toss out terms and descriptions: semistructured interviews, participant and interviewer, interview schedule, informed consent, guaranteed anonymity and confidentiality, transcriptions, coding categories. Each of these acts as "order words" carrying its own "little death sentence" (Deleuze \& Guattari, 1987, p. 7) implicitly carrying within it a whole history of 'qualitative' educational research.

In this paper, I want to interrogate the category of interview, and the habit of interviewing, so as to allow thinking of different ways of writing/speaking/representing the interactions between researcher and researched that will breathe new life into qualitative inquiries. Deleuze \& Guattari remind us that writers do not write on blank pages; the page "is already so covered with preexisting, preestablished clichés that it is first necessary to erase, to clean, to flatten, even to shred" (Deleuze \& Guattari, 1991, p. 204). I will attempt to disrupt the clichés, to destabilise and disrupt commonsense ideas about the interviewing process, including those held most sacred to the qualitative community, that of anonymity and confidentiality, as well as the privilege of the 'transcript' in representing interview data (Kuntz \& Presnall, 2012). 
In this paper I take up an ontology that draws on the work of Deleuze and Guattari (1987) to rethink the relations between researcher and researched, between language and materiality, between the acts of research collection and research analyses. Part of my intention here is to provide an opening for those researchers who are just embarking on their academic journeys, to give them permission to experiment, to play, to disrupt, what is taken-for-granted in qualitative research methods.

I draw here on Norman Denzin's (2010) description of the 'eighth moment' in the history of qualitative research. In this moment, researchers are called on to experiment with both writing forms and data collection methods. Denzin uses the term 'bricoleur' (2010, p. 29), to describe the researcher who blurs the boundaries between genres and narrative strategies, who experiments with new forms of writing and re-presentation of data.

Denzin's 'eighth moment' is operating similarly to the post-qualitative moment described by St Pierre and Lather (2013). The theoretical and methodological connections are provided through ontological approaches that "do not assume there is a given, a real world (data) that can be gathered together (collected) and described (analyzed and known)" (St Pierre, 2013, p. 225). Such an ontology also requires moving beyond a focus on language, rethinking the 'textual' to use different semiotic systems, such as voice, image, sound, but also thinking about language itself differently as well as the relations of language to the material world. As MacLure explains, such a "materially engaged language" would be "non-representational, non-interpretive, a-signifying, a-subjective, paradoxical and embroiled with matter" (MacLure, 2013, p. 663).

The post-qualitative moment creates a space to destabilise normative associations of research accounts with the primacy of language as the semiotic system used to describe and re-present the interactions within the "method assemblage" (Law, 2004, p. 41). I use the term 'method assemblage' after Law, to capture the "adhoc contingency of a collage" while also trying to explain the "active and evolving practices" of research methods (Law, 2004, p. 41).

In such an assemblage, as Mazzei argues:

there can no longer be a division between a field of reality (what we ask, what our participants tell us, and the places we inhabit), a field of representation (research narratives constructed after the interview), and a field of subjectivity (participants and researchers) (Mazzei, 2013, p. 735)

Within a method assemblage, the interview is itself an assemblage. In a discussion with Claire Parnet, Deleuze said an assemblage is always "a multiplicity made up of heterogeneous terms and which establishes liaisons, relations between them, across ages, sexes and reigns" 'co-functioning' "it is a symbiosis, a sympathy" (Deleuze \& Parnet, 2002, p. 69). An assemblage is not temporally fixed, the vitalism of the assemblage refers not only to the relations between and beyond materialities, but also to the disruption of the linear historical narrative.

I will create a method assemblage here, to try to capture the moment of the interview, to hold that unholdable moment, to freeze frame the action, image, and even the haecceity. Haecceity is, according to Deleuze and Guattari, "the mode of individuation very different from that of a person, subject, thing, or substance...consisting entirely of relations of movement and rest between molecules or particles, capacities to affect and be affected" (Deleuze \& Guattari, 1987, p. 261).

\section{"Achieving a successful interview"}

The title of this section is taken from a chapter of Interviewing for Social Scientists (Arksey \& Knight, 1999). The chapter echoes similar guides provided to qualitative researchers (for example, Kvale, 2007, Silverman, 1999), including advice and information about types of interviews (structured/unstructured), the use of 'interview schedules', and methods of recording (notetaking, audiotaping). There is even a kindly avuncular note on "personal appearance" that concludes with a recommendation to "invest in outfits that include the casual and informal, the fashionable and 
trendy, and also conservative-looking suits that signal you are a professional" (Arksey \& Knight, 1999, p. 104).

By their very nature, these guides create hierarchies and categories, numbered lists and ordered steps. I work with many postgraduate students, and I help them understand that research is messy, and not ordered. Some of them are dismayed when they enter into the data collection space to find that these spaces do not perform in hierarchical ways, that they cannot determine if their carefully pre-prepared questions are understood by their 'participants', that they have spent twenty minutes of a 30 minute interview talking excitedly with their participants about their responses to the first question listed on their interview schedules. Drawing on Law (2004), I try to help these researchers that method is messy, that preconceptions about method, about data collection, about the nature of linguistic interactions between two people, can and always/already are disrupted and challenged by the relations and movements in any particular moment. In this paper, I attempt to lay bare the messiness of the interview process, writing against the approaches that qualitative researchers have been trained in. As St Pierre (2013) reminds us, much of this research training has been conducted in itself as a counter to positivist social sciences, and in an effort to replicate the 'hard' Sciences, qualitative researchers "use concepts and practices like bias, objectivity, subjectivity statements, triangulation, audit trails, and interrater reliability that signal they are bound to logical positivism/empiricism, objectivism, and realism" (p. 224). So here I try to disrupt these and other terms, to interrogate the habitual use of the terms, to signal an unbounding to logic, to point to a different ontological project.

In the next section of this paper, I provide some background of the data even though in the act of writing this I realise how impossible that is to do. I draw on a piece of data collected as part of research in Papua New Guinea, and this is in itself a situation fraught with the complexities of postcolonialism, the histories of the anthropological gaze on Papua New Guineans, and the entanglements of race/ethnicity/gender/language of materiality's bodily movements. In what follows then, a seemingly straightforward account of a research project, I am aware of what is not said, the gaps that appear between the words on the page that hold invisibly the other stories, the other ways of describing the research design, the other accounts, the failures of method, the friction between team members. This account of data collection, of a research project conducted within the postcolonial space of Papua New Guinea becomes/is already then, part of the interview assemblage.

The data background

Between 2009 and 2012, I led a cross-cultural team investigating the use of action research as a vehicle for teachers' professional learning in remote areas of Papua New Guinea (Xxx et al., 2012). There were five team members working in the study, three of us from Australian universities, and two from the National Research Institute in PNG. During the three years, the five of us met regularly in Port Moresby, to discuss the study, to plan the progress, and to work with data collected. The two Papua New Guinean members of the team were responsible for implementing the project: that is, it was these two women who travelled to the remote districts of PNG to work with school teachers as guides and facilitators through the action research cycle. They collected the written work the teachers completed between visits, they took photographs of the schools and areas they travelled to, they videotaped their work with teachers as well as their journeys on canoes fitted with outboard motors up the Middle Fly and Sepik Rivers. They wrote 'research journals' and 'data reports'.

During our team meetings in Port Moresby, we also met with Department of Education officials, ran workshops for researchers and educators, and met with staff and students at the Papua New Guinea

This description is a simplistic overview of the intricacies and sensitivities associated with conducting research within postcolonial spaces. It ignores the privileges of the white Australian woman who carries with her the echoes of the historical relations between the two countries; it fails to acknowledge the status of Australia, and its neocolonial interference in the political, economic, and education systems of PNG. 
Institute (PNGEI), where teachers attend residential courses to upgrade their teaching qualifications from Certificate to Diploma level. Two of us had worked at PNGEI and knew many of the staff, and the processes and programs they ran, including the DEP(I) program (Diploma of Education Primary (Inservice)). The DEP(I) program runs on a 17 week semester, three times a year, and the enrolment in any one semester can be around 200 practising teachers, head teachers, and other members of the Education Department workforce, from across the country.

Part of our study included meeting with these DEP(I) students and sharing our data and results with them, as well as running seminars providing them with information about using action research. In 2011, during one of our team meeting visits, we heard that the Head Teacher of one of the remote schools involved in our study was enrolled in the DEP(I) program. During our scheduled seminar at PNGEI, we encouraged $\mathrm{Mr}$ Bagiya to contribute his understanding of action research and he spent some time answering questions from his colleagues about the study. At the end of the seminar, I asked him if I could interview him and record that interview, and he agreed.

Of course, he agreed! In this space/place, his authority as senior teacher, as an older man in a society where age and experience is accorded deep respect, was usurped. However, he could take up another position of authority under the gaze of his colleagues. They watched him become part of our research assemblage, part of the pack (Deleuze \& Guattari, 1987, p. 31). He stood with us during the seminar, they watched as I took him aside to ask about the interview, they walked past as we sat and talked outside.

\section{The routines of interviews}

The traditional account of a research interview often begins with a description of reasons for selection of a particular interviewee, and some of the 'participant's demographic characteristics' (Holstein \& Gubrium, 2004). There is often an explanation of the 'type' or the 'category' as well as an indication of the questions (Arksey \& Knight, 1999). Information about gaining informed consent, about guarantee of anonymity and confidentiality is provided (Hannabuss, 1996), and often this is followed by a brief description of the 'participant', bland enough so that he or she cannot be identified (see Acevedo Nistal et al, 2013, p. 106).

None of this captures the relations between affects and movements, between haecceity and abstract machines. The movement of the actors, the sounds of the voices, the background noises, and the discursive mappings through to other moments of time need images, sound, and names. They need more than the 'rich thick descriptions' (Creswell \& Miller, 2000) that are stripped of any colour or movement, that are so poverty struck it is impossible to detect any life, any (in)dividuation. In the next sections, I will examine each of the habits of interview and provide my own re-representation of these parts of the research performance. In each of these sections, I draw on a range of everyday, widely available resources to describe the 'norm' of qualitative interviewing. This is the kind of 'surveying' of methodological literature that many doctoral students engage in to set up their research studies.

Samples

What is a sample? Of course, I move immediately to that source of all and infinite knowledge about research methods, Google, which takes me instantly to the 'dictionary definition' - handy as an introduction to the section of my report on 'methods': 


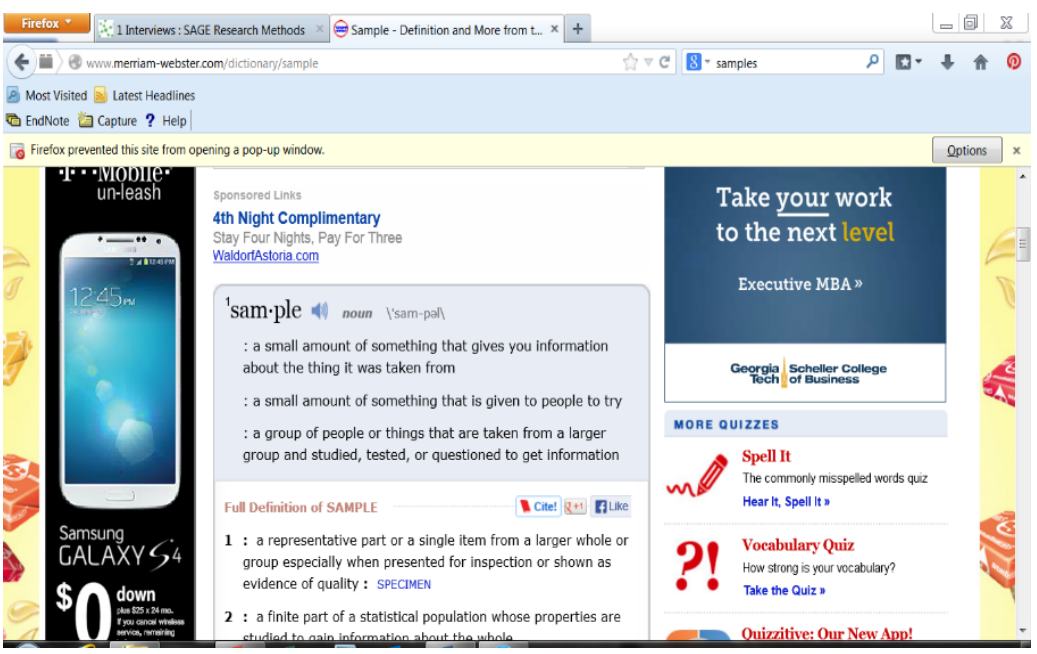

Figure 1http://www.merriam-webster.com/dictionary/sample
The population for this study comprised of 60 Ordinary level students in all the secondary schools in Chivi district that are offering food and nutrition as a subject at Ordinary level, 5 school heads and 3 Food and nutrition teachers. The sample comprised of 20 students, 10 parents chosen by a simple random sampling technique. The three teachers and the five school heads automatically became part of the sample (Shadreck, 2012, p. 780)

So how does Mr Bagiya perform a sample? How does he become a sample? Did I enact 'purposive' sampling (Sampling Logic, 2007), when I asked him if I could interview him? (See the example of 'sampling' from Shadreck, 2012).

What is he a sample of?

It is the $22^{\text {nd }}$ November 2011 (I know this because of the date stamp on the digital MP3 file of the interview). It is hot (I know this because I have worked in Port Moresby, it is always hot. And as I type these words nearly two years later, I feel the sweat trickling down my stomach, as it always does and did when I stand to talk to groups of students at PNGEI). We are in the 'mess', painted pale green, concrete floor, aluminium kitchen tables and plastic orange chairs, the teachers/students sit in front of us, I talk and talk and talk, the sweat trickles. Every time l look at Bagiya, he nods and smiles, affirmatively, agreeably, saying yes to everything I say. At the end of the session, I say, can we sit outside, can we talk outside, can I put the tape on, can I interview you now. I'm pretty sure I don't even listen for his answers because I know they will be yes, yes, yes. Yes I am being arrogant here, yes I know that here I am taking up a power(full) position as a white women.

\section{From the data files}

Mr Bagiya is a Head Teacher at one of the four schools participating in the action research component of our study. He is currently enrolled in the DEP(I) program at PNGEI. He has been actively supportive of the study, and the researcher visiting his school has suggested a follow up interview with $\mathrm{Mr}$ Bagiya could provide extra information about the reasons for this support. Mr Bagiya has been teaching for many years in Western Province, especially around the Balimo/Daru area where he is currently located.

\section{Day $2(16 / 03 / 10)$ - Tuesday}

In the afternoon of day 2 the Biyawa Head Teacher arrives on his bicycle to check if I was visiting their school. He had heard that I was coming. He said, "We are waiting for you". 


\section{School SB - Biyawa School}

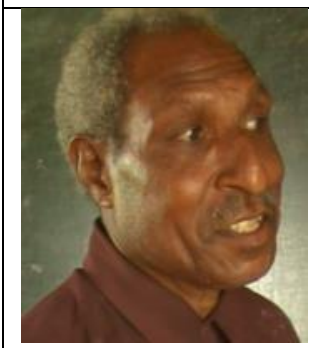

Sowati Bagiya - Head teacher grade 6

Staffing

\begin{tabular}{|l|c|c|c|c|}
\hline \multicolumn{1}{|c|}{ Name } & Gender & Teaching Position & Grade & First language \\
& & & Teaching & \\
\hline Sowati Bagiya & Male & Head Teacher & 6 & Gogodala \\
\hline
\end{tabular}

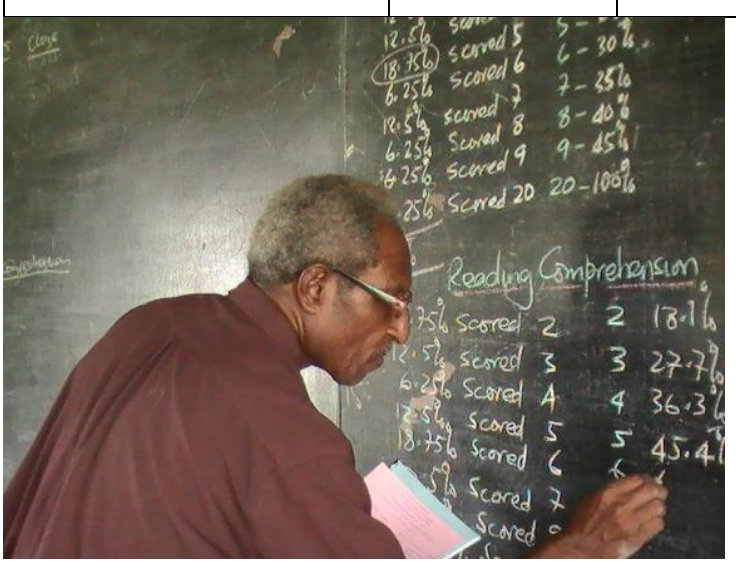

Figure 2 Head teacher analysing data collected by teachers 
From the research journal

\section{Biyawa Primary School}

This school is about an hour boat ride from Balimo station. It takes longer by road because the road is in appalling conditions. Even four-wheel drive vehicles cannot get through the roads in this area during the wet days. This school was established in the mid 2000s- a more recent established primary school. The school is surrounded by wet lands. There is so much black-brown water and enormous masses of floating grass, water lilies and a rich variety of bird life in the wetlands and other creatures in the water such as crocodiles.

The school student population is $\mathbf{1 4 8}$. The head teacher was unable to give me the exact number of students in each class by gender. I noted (verbal information) that classes are small in this school. I encouraged him to have this ready during the next visit.

There are two new double classroom buildings and three new teachers' houses built by the current MP for Middle Fly Open. All the teachers are housed in the school grounds. All the three teachers' houses have water tanks. There is also one in the classroom area. The Grade 3 is housed in an old class room- a left over section of the old school infrastructure, while the other grades are housed in the new classroom buildings. Toilets (pits) facilities is not an issue in both the school and staff houses. There is no library building or a library of any sort in the school.

\footnotetext{
James Chalmers of the London Missionary Society was the first white man to contact the Gogodalas in 1899. Early in 1900 Chalmers planned to make Gaima, a Gogodala village on the Fly River, his base for evangelizing the area but the project was shattered when he, Tomkins, and eleven Kiwai teachers were killed by the Goaribaris. Papuan Industries, an industrial mission, started a copra and rubber plantation at Madiri on the south bank of the Fly opposite the Gogodala area in 1910. The aim of the mission was to improve the material, moral and spiritual life of the local inhabitants by industrial pursuits. (Weymouth, 1984, p. 271)
}

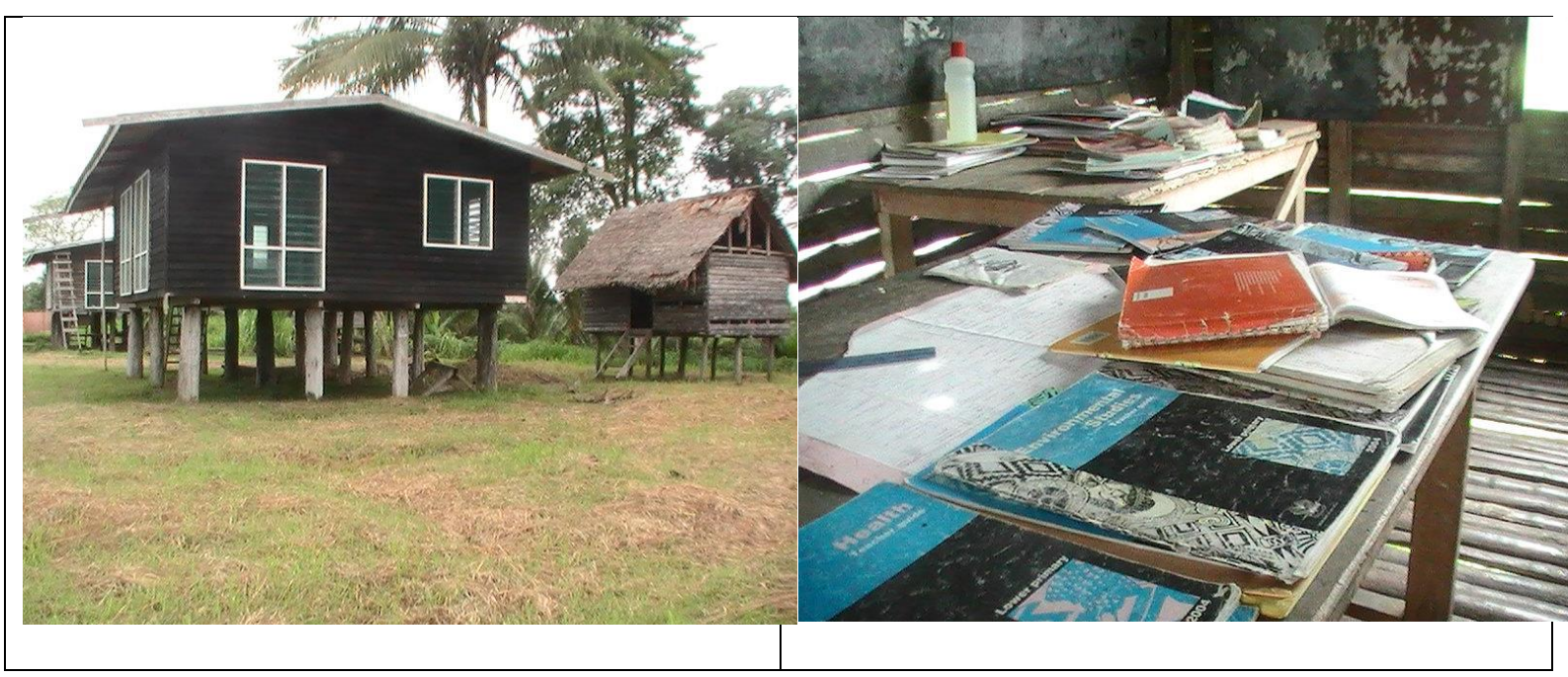

I attempt here to provide more than what is usually captured in a description of an interview interaction. Within interpretivist theoretical paradigms, it is taken for granted that an interview only captures what is said at that time or in that place (see Kvale, 2007, for example). However, this social constructionist view of reality being constituted within a particular moment fails to capture the 
assemblage of meanings created within that particular moment that emerge from historical, social, economic, and material conditions. This is not the essence of Mr Bagiya, this does not even capture the Mr Bagiya I interviewed. Some of this I had encountered before I talked to him that day. Parts of the person I spoke to that day were assembled from the generalisations I make when I talk to Papua New Guineans, when I speak to Papua New Guinean men, when I interact with Papua New Guinean teachers. And yes, the "I" of which I speak here is an assemblage of positions and discourses and materialities. Other parts are assembled from the colonial historical relations of our two countries, from the role Australia has taken in education, through funding and technical advice on policy and curriculum, from my position as representative of the Australian education machine.

This is how we create the interview machine, the assemblage at that moment, with us in that moment, the us that is there, then, not here and now (Lambert, 2006).

Informed consent, guaranteed anonymity and confidentiality

Anonymity and confidentiality must be assured.

$$
\begin{aligned}
& \text { Anonymity = Invisibility; Confidentiality = Secrecy; } \\
& \text { Ethical=Hidden, False? }
\end{aligned}
$$$$
\text { Anonymity }=\text { protect the identity of participants }
$$

Our practices as researchers are governed by the perceptions of 'ethical' research and what is accepted as 'ethical' by committees and institutional review boards (Honan et al 2012), while at the same time we struggle to understand how these macroethical processes are embodied in the microethical moments of performing research (Guillemin \& Gillam, 2004).

In many ways, attempting to write of this research interview is impossible given the restrictions of the 'normal' approvals to conduct ethical research.

So it would appear that in the first part of this paper I have breached these guidelines. I have used Mr Bagiya's name, I have told you where he comes from, the school where he works that he is a Head Teacher, and I have shown you photographs of him and his school. Yet, the ethical conduct of research in Papua New Guinea requires far more than what is captured on the forms of an ethics application (and how do I know that I have acted ethically? Who am I to say?)

\subsubsection{Participants are often easily identifiable (for example, as members of small communities or groups, or as key informants), and the information they provide may be sensitive. For these reasons, care should be taken that participants are not identifiable by the information they provide, unless they have agreed to be identified. Special care should be taken to protect the identity of participants when disseminating information and storing material (NHMRC guidelines, 2007)}

In an account of one piece of work completed in PNG, my colleagues and I wrote:

teachers expressed not only a willingness to engage in our research but also a profound gratitude for our selection of their schools. This gratitude was expressed through the gifts given to the Australian members of the team in schools in Port Moresby, through prayers and speeches offered to the members of the team when visiting and working with teachers in the elementary schools, and through the written reflections of the teachers undertaking the action research projects ('God bless Richard', wrote one teacher in her reflective journal) (Evans et al, 2010, p. 84).

Signing names on pieces of paper, not attaching the names of people to the words they speak, are signals of unethical practices in PNG. Histories of the anthropological gaze, colonial bureaucracy, and the legacy of the village kiap who was the representative of this bureaucracy, as well as the postcolonial experiences of land seizures by mining and forestry companies infiltrate the relations between 'researchers' and 'participants' (Evans et al., 2010). Thrust a piece of paper in a teacher's hand and ask for a signature, and she/he usually will, just to please you, just to make you happy. Sit down and talk about your project, talk about trust, and sharing, and good will, and teachers will 
respond with prayers and gifts and good wishes. Indeed as the research journal collected by one of my colleagues records:

The teachers in both primary schools were enthusiastic about participating in the research so they willingly signed the consent forms. (B-V1-DR)

Importantly, they want to be hailed, they want to be recognised, (that is me, I said that, those are my words, that is my work). Teachers who are asked to work with researchers seem to think it is an honour, they have been selected for special work, and they want everyone to know about it.

In some ways then, I can make a claim to ethical practice in naming Mr Bagiya while at the same time appearing to be in breach of ethical guidelines. I provide the face, details, history, I try to show you a man rather than describe a participant, show you how he and I, older Papua New Guinean male head teacher, and white academic know-it-all Australian woman, how we sit and talk to each other, rather than provide a transcript and analysis of a research interview. Anonymity, guarantees of confidentiality, "protect the identity of participants" (NHMRC, 2007) are methods of keeping the 'identity' of the 'informant' secret. Yet Deleuze and Guattari remind us that a secret is only a secret because someone has gained knowledge of that secret, it is only in the disclosure that the secret appears as an entity, if the secret is truly a secret, then it is not a secret, it is nothing, a void box. "The secret was invented by society; it is a sociological or social notion. Every secret is a collective assemblage" (1987, p. 287).

I now tell my secret, this is Mr Bagiya, Head Teacher from Biyawa Primary School in the Western Province of PNG. Ha! All I have done is ascribe a name to a photograph, a title to a man, a location to his place. Maybe my secret is that I have invented it all?

I am conscious also of the freedom in writing about this moment, this interview, this man, this research, knowing that none of those involved will ever read this paper, or will have any interest in reading this paper. So maybe the secret is the writing of this paper, and you, as reader are colluding in the construction of the secret? I am also aware of my authorial authority in the construction of this moment, this version of Mr Bagiya, this representation of him on the page.

\section{Structure/semi structure/destructure}

Sage and wise advice about the nature of interviews and the difference between 'structured' and 'unstructured' qualitative interviews can be found throughout research methods courses, papers, books, and websites (Arksey \& Knight, 1999, Kvale, 2007, Silverman, 1999). Even the NHMRC ${ }^{1}$ guidelines (2007, p. 26) provide this helpful explanation:

Interviews can take many forms, including:

- structured interviews, which follow a set list of questions;

- semi-structured interviews, which use an interview guide listing a set of issues to be explored;

- unstructured interviews, which involve spontaneous generation of questions in the natural flow of interaction, and where the interview is driven by the interviewee rather than the interviewer.

(I actually don't remember this but my voice is so loud on the recording it must be in my hand)

\section{An unstructured interview}

Here I try to destructure/unstructure the process of interviewing. I use my notes, the recording, my memories.

I don't have a set of questions prepared. We walk from the mess out into the heat of an after school afternoon. It is past 3, school students from next door wander past, a couple of teacher/students sit nearby lethargically chewing buai and muttering to each other.

\footnotetext{
${ }^{1}$ NHMRC - National Health and Medical Research Counsil.
} 
We sit on the 'garden' bench, side by side. I put the digital recorder on the bench between us and then, it doesn't look very stable, I pick it up again and hold it in my hand.

What will we talk about? Why am I here talking to this man?
What I really want to know is what is it like being a teacher, being a representative of western privilege, of the infiltration of neoliberal bureaucracies into PNG education,

The language I use to ask these questions shifts so the questions I hear on the recording are mundane, trite:

And so, so it sounds like you had you had warning that she was coming (yes, yes) and you think that's

Why do people think you are a good teacher? You look like an old run man to me, how can you be a model of school leadership? What is a model of school leadership here? I've got definite ideas about what is good about PNG schools, do you agree with my ideas? Do you really get the idea of action research or are you just saying it is great because it's better than nothing? Why are you different? We have a clip of you with one of your young male teachers showing you what to do, guiding you through the reading of a document, why have you let him show you what to do? really important? (yes) Yes? (yes)

And how did you get that warning?

So did he come to visit you or?

Ok so you just happened to be there? Doing some other school business? Yeah?

Or questions that reaffirm what Mr Bagiya has just said, sounds like I don't believe him?

Do you come from that area? (no) No? (no)

And so can you go to the board of management and say look I don't want that teacher? (no no) you can't? (I can't, laughs) you're not allowed to? (laugh no no)

Or irrelevant - how did we end up talking about reading materials?:

You mentioned newspapers? (newspapers) and magazines? (magazines) what kind of magazines? It's a religious one?

So is there a trade store at your?

\author{
And do they sell reading materials of any kind? \\ They don't have newspapers? \\ Why, How do you learn to read when there are no \\ reading materials around you? \\ And what about the last school you were at? \\ Before? \\ So did they have reading materials? \\ So what kind of materials did they have? \\ In their homes? \\ In their homes? As well as in the school? \\ So are there many materials in that language? (no) \\ around (no)
}

On a recording of 27:55 minutes, there are only four questions that appear to be 'research questions' four that are related to the research study questions, and that resemble the questions that I was thinking about before we sat down to talk.

Why do you think it worked at your school? What was it that helped your school to implement the action research?

So what do you see as the good, what's the good relationship between a head teacher and staff? 
So what makes a good teacher then?.. if you had if you could choose?

Will this work? Will using the booklet work without having someone like Patricia coming to your school?

Should I have prepared a set of questions to ask? Could I really have posed a question such as:

Tell me what it is like being a man from Gogodola, whose history with the western ontology and epistemology that constructs the modern schooling system in PNG has only been 100 years, whose great grandfather had never interacted with the ideas of the Enlightenment, who comes from a group of people described by anthropologists as 'savages', 'cannibals' and 'sorcerers', tell me what it is like to be that kind of man being a teacher?

And if I can't ask that question then why bother asking anything? And how do these types of questions, (about culture, about history, about the neocolonial between Australia and Papua New Guinea, about the place of a 'modern' education system within PNG), get asked by someone like me? Should I not be there at all?

\section{Participant and Interviewer}

It has become commonplace and routine to regularly explain the unequal power relations between interviewer and subject/participant/ interviewee (Kvale, 2006).

We are all 'good' qualitative researchers who have learned about our powerful positions, and carefully use words and space to describe these relations. But then we move on, done with the confessional, we jump out of the wooden cubicle to sin again, cleansed for the moment by the sacrament of reflexivity. As Mazzei \& Jackson (2012) remind us:

Letting readers "hear" participant voices and presenting their "exact words" as if they are transparent is a move that fails to consider how as researchers we are always already shaping those "exact words" through the unequal power relationships present and by our own exploitative research agendas and timelines (Mazzei \& Jackson, 2012, p. 746)

The qualitative research interview entails a hierarchical relationship with an asymmetrical power distribution of interviewer and interviewee. It is a one-way dialogue, an instrumental and indirect conversation, where the interviewer upholds a monopoly of interpretation (Kvale, 2006, p. 484)

We choose the words, we choose the placement of the words on the page, we choose the moment to capture, we guide the gaze of you, the reader, into the moment when the subject reveals 'all':

Do you know Mr Bagiya yet? Do I?

Within a neo-romantic cult of the spontaneous narrating self, the interview is regarded as providing an authentic gaze into the other's soul, and the experiential narratives as a dialogical revelation of an authentic inner self. (Kvale, 2006, p. 493)

And if there is no 'inner self' to know, if the post qualitative ontology requires us to "give up phenomenology", then "we can no longer privilege

So what am I doing using interviews as a data collection method? And what takes their place? How do we do data differently? the immediacy, the "now," the "being there" of qualitative interviewing and observation that assume both the "presence" of essential voices and the foundational nature of authentic lived experience" (Lather \& St Pierre, 2013, p. 630). 
Maggie MacLure asks us not to create 'angels' with "no social fabrication or historical entanglements" (2013, p. 664), the angels who Lecercle (2002, p. 87) tells us "do not speak dialects, they do not have a social or regional accent or lexicon".

\section{Transcriptions, coding categories}

An important part of reducing the assemblage of Mr Bagiya to a cardboard cutout approximation that responds to the requirements for academic rigour in educational research is the act of transcription. The heavy labour of transcribing, the pain, the monotony, seems at odds with the dangerous work of a "traitor" (Kvale, 2007), and indeed Kvale recommends the use of a "good typist", although this feminized transcribing machine can of course now be augmented with other automated digital processes, including the semi-digital international transcribing services that have saved many a doctoral student from the grubby and timeconsuming process of actually listening to the interview data collected.
But when our words are flattened onto a page, when Mr Bagiya appears to be a Flat Stanley creation, with words created from my imagination, when I hold the words in my head, in my power, when the only way you can listen to him speak is via me, when you do not hear his accent, the way he emphasises some words, the doubtful way he says, $\mathrm{mm}$ yes, as if he is humouring a little child, the way I think sometimes he doesn't understand my question or I didn't understand his answer, then how can he be more than one of the "boring, bloodless angels" (MacLure, 2013, p. 665) that float across the pages of qualitative research accounts.

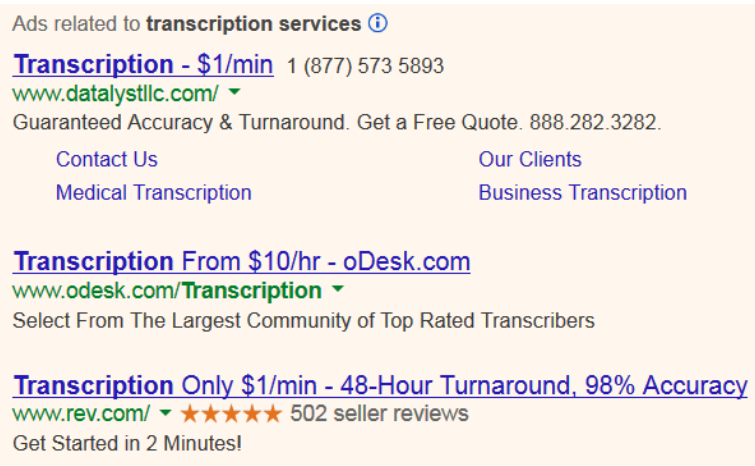

Qualitative researchers happily remind each other of the dangers continue to use the transcription as the holy text of the research report. Even those of us dabbling and playing within the pool of postqualitative re-presentations of data cannot seem to move away from the transcript (see for e.g., chapters in Coleman \& Ringrose, 2013). As St. Pierre explains patiently:

we believe we must translate whatever we think are data into language, code that language, then cut up pages of text in order to sort those coded data bits into categories, and produce knowledge based on those categories, which, in the end, are simply words... Yet how can language, which regularly falls apart, secure meaning and truth?" (St Pierre, 1997, p. 179)

But our textual world demands this of us.

What might it mean to seek those discarded and discounted qualities that not only complicate but also enrich meaning and the research text? That this spoken voice is not easily "captured" or "contained" is not cause for despair (Mazzei \& Jackson, 2012, p. 746) 
Mazzei has created a figuration of the "voice without organs" (Mazzei, 2013) to destabilise the boundaries between the discursive and material, to unfix the speaking subject from the fixing of words on the page. In her work to rethink voice, she captures and describes the silenced, the gestures and embodied responses to her questions, but we still don't hear the women. How do they speak? Are they soft or do they yell? Do they use the accent of the US south?

So in this transcript of Mr Bagiya, can you hear him?

We must use The Word. Even in this manuscript, I try to insert a MP3 file of the voice of Mr Bagiya, saying the words that I have noted and transcribed. But even in this latest version of Office, I can insert screenshots, smart art, charts, online pictures, and online videos, but not sound files. Sound without image is not heard, sound that is not translated into text does not exist.

But when we are alone and we don't cooperate with them, or in social gatherings, we don't sit down with them and talk about it they will say, they will look at us in the way that you have mentioned that, you know, you are highly respected teachers and you know what you are doing you know why should we tell you something to do about that ( $\mathrm{mmm}$ ) system ( $\mathrm{mmm}$ yep) but if we umm bring ourselves to their level, (mmmm) uum yeah, as a as a community member, (yeah) yeah as we say I'm not a teacher, after all that umm, 8 to 3 to 4.06 is finished, I'm only just like you (yes), I'm an ordinary village man like you (yes) yeah, then they will be able to share (yeah) what they know.. (wow yeah ok well that's interesting), yeah (16.45)

I now make use of the affordances of the digital spaces available to me, a clip from the recording is merged with a

And does that word for word "verbatim" transcript that took me about 30 minutes to transcribe tell you more or less or different things about Mr Bagiya than the notes I took when I first listened to the recording (sitting on a plane between Port Moresby and Brisbane)
We need to be like them and sit down and chat with them if we don't sit down and chat with them in social gatherings they won't do that if we bring themselves to their level at the community level after all I'm only a teacher between eight and three and then after that I'm just a village man. screenshot from one of the video recordings made during data collection visits to Balimo, a 'movie' is created and uploaded to YouTube, and here is Mr Bagiya saying the words from this transcript. (http://youtu.be/5zKlxonKJuE) 
(But is this his voice? Are these his words? Has he said the words or is he reading from the transcript?)

I argue that the "reification of the transcript as the primary artefact of the interview" (Kuntz \& Presnall, 2012, p. 733) creates an artificial reality, a clichéd representation of the interactions that occur between two people at one particular moment in time. This moment in time is part of the 'method assemblage' (Law, 2004, p. 41) that creates a research study.

\section{And so? And?}

So what? How does this playing with words, this juxtaposition of text, image and sound on the page, this deconstruction and interrogation of the habits of interview help further the ontological project of thinking data differently?

In this paper, I wanted to provide an illustration of what happens when the interview as a method is interrogated as well as provide an illustration of what it means to write differently about interview, method, and the research assemblage.

Even in these times and moments of post-qualitative research, the interview is granted sacred status. Many working within these new spaces have interrogated and destabilised this positioning of the interview as an insight into 'the real story' (see Mazzei, 2012). There are many habits of interviewing and qualitative researching and reporting that block this re-positioning including our need to grant anonymity, our use of word processing software as a publishing tool, our blind faith in the power of language to re-present the story of the interview encounter. In this paper, I have attempted to play with each of these habits, to show a different way of re-presenting the interview assemblage.

Each of these blockages could be viewed as external to the assemblage of qualitative research. We complain of the restrictions imposed by ethics committees and IRBs and we decry the unidimensional approach to writing demanded by journal editors, thesis examiners, and university committees. Yet each time we take to the keyboard, pick up the pen, and begin the draft of another research reporting text, we inhale the habitual, we follow the lines of longitude and latitude that border the space, we patrol the boundaries of the page.

In Deleuzean terms, this work is about the cutting edges of deterritorialization, which carry it [the assemblage] away $(1987$, p. 88). It is about pushing the boundaries of the re-presentation of the interview process. Pushing these boundaries requires ontological work as well as methodological, and both new and different ontological and methodological paradigms require new and different ways of writing, of thinking about language, of representing knowledge differently.

It is the writing part of the process that is most difficult. We can think knowledge differently, we can even sometimes create images, sounds and words that re-present knowledge differently, but the creation of a piece of written text that both uses signifiers while at the same time challenging them, this is the moment when language moves beyond the binary between content and expression. I have attempted to illustrate here what Deleuze refers to as a "Spinozist theory of language in which the flows of content and expression don't depend on signifiers: language as a system of continuous flows of content and expression, intersected by machinic arrangements of discrete discontinuous figures" (Deleuze, 1995, p. 21). 
Writing other ways of interviewing into existence involves "treating writing as a flow, as one flow among others, a flow meeting other flows. It involves shifting, slipping, dislocations, hidden emissions, affects, intensities, experiences, experiments, points of contact, chance encounters, coincidences" (Honan, 2007).

How does this writing occur? Drawing difference helps. As Deleuze tells us, we need to draw "something new from repetition" (Deleuze, 1994, p. 76). To me, this means paying close and careful and critical attention to the assumptions we make as researchers, to remind ourselves of the habits of our practices, to disrupt and interrogate those practices in order to create something different.

Avoiding "weasel words" (Watson, 2004) is one way of drawing something new. Those words that are empty and hollow, that slip glibly from our tongues onto the page.

And is 'interview' or even 'qualitative' one of those empty signifiers?

This is difficult work. The writing can "close right up on itself"

(Deleuze $(1995$, p. 14). There are no models, no templates to follow, no writing gurus, no "personal thesis coaching" (www.3monththesis.com).

But to return to Denzin's description of the researcher as bricoleur who enacts the eighth moment, writing as a form of experimentation is required. Letting go, giving permission to others to let go of forms and structures, of style guides and academic conventions, provides spaces for us to think and present knowledge differently.

\section{References}

Acevedo Nistal, A., Van Dooren, W. \& Verschaffel, L. (2013). Students' reported justifications for their representational choices in linear function problems: an interview study, Educational Studies, 39(1), 104-117

Arksey, H., \& Knight, P. T. (1999). Interviewing for social scientists: An introductory resource with examples. London: Sage.

Coleman, R. and Ringrose, J. (Eds.) (2013). Deleuze and research methodologies. Edinburgh: Edinburgh University Press.

Creswell, J. W., \& Miller, D. L. (2000). Determining validity in qualitative inquiry. Theory into practice, 39(3), 124-130. http://dx.doi.org/10.1207/s15430421tip3903 2

Deleuze, G., \& Guattari, F. (1987). A thousand plateaus. Capitalism and schizophrenia. London: The Athlone Press.

Deleuze, G., \& Guattari, F. (1991). What is Philosophy, New York: Columbia University Press.

Deleuze, G. (1994). Difference and repetition (P. Patton, Trans.). New York: Columbia University Press.

Deleuze, G. (1995). Negotiations: 1972-1990: New York: Columbia University Press.

Deleuze, G. \& Parnet, C. (2002). Dialogues II. New York, NY: Columbia University Press.

Denzin, N. K. (2010). The qualitative manifesto: a call to arms, Walnut Creek CA: Left Coast Press.

Evans, T, Guy, R, Honan, E, Muspratt, S \& Paraide P. (2010). Reflections on conducting educational research projects in Papua New Guinea. Journal of Research and Reflections in Education, 4 (2), $72-89$.

Guillemin, M., \& Gillam. L (2004). Ethics, reflexivity, and "ethically important moments" in research. Qualitative Inquiry 10(2), 261-280. http://dx.doi.org/10.1177/1077800403262360

Hannabuss, S. (1996). Research interviews, New Library World, 97(5), $22-30$.

Holstein, J \& Gubrium, J. (2004). The active interview. In D. Silverman: Qualitative research: Theory, method and practice (2nd ed., pp. 140-161). London. Sage.

Honan, E (2007). Writing a rhizome: an (im)plausible methodology. International Journal of Qualitative Studies in Education, 20 (5), 531-546. http://dx.doi.org/10.1080/09518390600923735 
Honan, E., Hamid, M. O., Alhamdan, B., Phommalangsy, P., \& Lingard, B. (2012). Ethical issues in cross-cultural research. International Journal of Research \& Method in Education, 36(4), 386399. http://dx.doi.org/10.1080/1743727X.2012.705275

Kuntz, A. M., \& Presnall, M. M. (2012). Wandering the Tactical: From Interview to Intraview. Qualitative Inquiry, 18(9), 732-744. http://dx.doi.org/10.1177/1077800412453016

Kvale, S. (2006). Dominance through interviews and dialogues. Qualitative Inquiry, 12(3), 480-500. http://dx.doi.org/10.1177/1077800406286235

Kvale, S. (2007). Doing Interviews. SAGE Publications, Ltd. London, England: SAGE Publications, Ltd.

Lambert, G. (2006). Who's afraid of Deleuze and Guattari? London: Continuum International Publishing Group.

Lather, P. (2013). Methodology-21: what do we do in the afterward? International Journal of Qualitative Studies in Education, 26(6), 634-645, http://dx.doi.org/10.1080/09518398.2013.788753

Lather, P., \& St. Pierre, E. A. (2013). Post-qualitative research. International Journal of Qualitative Studies in Education, 26(6), 629-633. http://dx.doi.org/10.1080/09518398.2013.788752

Law, J. (2004). After method: Mess in social science research. Oxford and New York: Routledge.

Lecercle, J.-J. (2002). Deleuze and language. Hampshire UK: Palgrave Macmillan. http://dx.doi.org/10.1057/9780230599956

MacLure, M. (2013). Researching without representation? Language and materiality in postqualitative methodology, International Journal of Qualitative Studies in Education, 26(6), 658667.

Mazzei, L. (2013). A voice without organs: interviewing in posthumanist research, International Journal of Qualitative Studies in Education, 26(6), 732-740.

Mazzei, L. A., \& Jackson, A. Y. (2012). Complicating voice in a refusal to "Let participants speak for themselves". Qualitative Inquiry, 18(9), 745-751.

http://dx.doi.org/10.1177/1077800412453017

National Health and Medical Research Council, the Australian Research Council and the Australian Vice-Chancellors' Committee. (2007) National Statement on Ethical Conduct in Human Research. 2007 (Updated May 2013).

http://www.nhmrc.gov.au/_files_nhmrc/publications/attachments/e72_national_statement_ 130813.pdf

Sandelowski, M. (2002). Reembodying Qualitative Inquiry, Qualitative Health Research 12 (1), 104115.

Sampling Logic. (2007). In Thomas A. Schwandt (Ed.), The SAGE Dictionary of Qualitative Inquiry. (3 $3^{\text {rd }}$ ed., pp. 270-272). Thousand Oaks, CA: SAGE Publications, Inc. Retrieved from http://srmo.sagepub.com.ezproxy.library.uq.edu.au/view/the-sage-dictionary-of-qualitativeinquiry/SAGE.xml

Seidman, I (1998). Interviewing as qualitative research: A guide for researchers in education and the social sciences. New York. Teacher College Press.

Sellers, M., \& Honan, E. (2007). Putting Rhizomes to Work:(E) merging Methodologies. New Zealand Research in Early Childhood Education, 10 (1), 145-156.

Shadreck, M. (2012). Challenges of Implementing the Food and Nutrition Curriculum in Secondary Schools in Chivi district, Zimbabwe, Journal of Emerging Trends in Educational Research and Policy Studies, 3(5), 779-783.

Silverman, D. (1997). Qualitative research: theory, method and practice. London: Sage.

St. Pierre, E. A. (1997). Methodology in the fold and the irruption of transgressive data. Qualitative studies in education, 10(2), 175-189. http://dx.doi.org/10.1080/095183997237278

St. Pierre, E. A. (2013). The Appearance of Data. Cultural Studies $\leftrightarrow$ Critical Methodologies, 13(4), 223-227. http://dx.doi.org/10.1177/1532708613487862

Watson, D. (2004). Death Sentence: The Decay of Public Language. Milsons Point, N.S.W: Vintage Australia. 
Weymouth, R. M. (1984). The Gogodala Society: A Study of Adjustment Movements since 1966. Oceania, 54(4), 269-288. 